\title{
The Absorption of Fats and Lipoids in the Plaice (P. platessa L.).
}

\author{
By
}

Ben Dawes, A.R.C.S., D.I.C.,

Research Assistant at the Plymouth Laboratory.

With 11 Figures in the Text.

\section{CONTENTS.}

Introduction .

Historical $=0$

Brief Statement on the Technique of Fat Staining . . . . . . . 77

Material and Methods . . . . . . . . . . . . 78

Notes on the Morphology and Histology of the Alimentary Tract _ . . 79

Protocols (1) to $(7)$. . . . . . . . . . . 80

Absorption of Fats and Lipoids in the Stomach $\quad . \quad$. . . . $\quad .90$

Absorption in the Duodenum, Pyloric cæca, Intestine and Rectum . . . 91

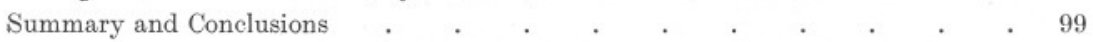

Literature . . . . . . . . . . . . 100

\section{INTRODUCTION.}

IN a previous paper, an account was given of the histological structure of the alimentary tract of the plaice, which account was submitted as the basis of a series of studies on secretion and on the digestion and absorption of food substances in this fish. The aim of the work which is to be described presently is to show histologically how fats and lipoids are transported through the mucosa of the various regions of the alimentary tract and to indicate which regions are most concerned with the absorption of these substances. The possible function of lipoids as intermediary products in the resynthesis of true fat within the epithelial cells is considered and discussed briefly. The rôle of mitochondria and golgi elements in fat absorption has not been determined, presenting as it does a distinct and separate problem, but useful fat pictures have been obtained, as have also data on the question of absorption in fishes.

\section{HISTORICAL.}

It appears that Weber (1847) was one of the first workers to demonstrate histologically the absorption of fat. He observed that during 
fat digestion and absorption the cells of the duodenal villi become swollen and opaque, or filled with transparent, oily fluid. Kölliker (1857) demonstrated the absorption of fat by the stomach of the mouse, cat and dog, and observed that fat is always present in the gastric mucosa in variable quantities from the second day after birth onwards. Krehl (1890) showed that fat is taken up in solution and not in globular form and that it is re-formed into droplets within the cells of intestinal ephithelia. His observations and conclusions received support from Pflüger (1900). Schilling (1901) observed fat in the gastric epithelium of the calf after a milk meal and noted the occurrence of fat droplets in the connective tissue beneath this epithelium and also in the lymphatic glands. In 1908, van Herwerden published comprehensive studies on gastric digestion in fishes, chiefly sharks but also teleosts. He fed fish artificially with oil or egg-yolk emulsions and observed that a number of hours later, fat drops were to be found in great numbers in the epithelia and sub-mucosæ, which tissues he noted as being free from fat during starvation. His work appears to be the first of its kind carried out upon fishes. Greene (1912) demonstrated histologically the absorption of fats by the stomach of the salmon, later (1913) extending his observations to include all regions of the alimentary tract, finding that the primary function of the pyloric cæca is that of fat absorption.

A host of workers attacked the problem from the chemical point of view, and it is interesting if not entirely relevant to consider briefly the general trend of this work. Marcet (1858) and Cash (1880) were concerned with the lipolytic properties of mucosa extracts, noting increased fattyacid content of the stomach during the digestion of a fat meal. Interest centred chiefly on the questions of the reversibility of lipolytic activity and the resynthesis of fats, and the researches of Brucke, Rochford, Monk, Moore and Rockwood, Ewald, Hamburger, Cunningham and others led to the classical investigations of Kastle and Lœvenhart (1900). From these investigations it is held that fats are first split up into fattyacids and glycerol, which products pass through the borders of alimentary epithelia to be resynthesised to form fat again within the epithelium cells as a result of the reversible nature of lipolytic activity. Moore (1903) and Frank and Ritter (1906) could find no evidence of the occurrence of resynthesis " in vitro " and the theory does not receive universal support. Bradley (1913) attempted to discover some correlation between the quantities of storage fat and the concentration of lipase in certain tissues of a variety of marine animals. Instead of correlation, he found that some of the tissues richest in fat are poorest in lipase and vice versa, and concludes that a comparison of fat and lipase in animal tissues gives no positive evidence in support of the theory of enzyme synthesis.

It is generally accepted, however, that the cleavage products of fats are 
passed through the clear margins of epithelia to be resynthesised in some way to form fats again within the cells. Mayer, Rathery and Schæffer (1914) suggested that mitochondria possibly supply phospholipid which serves as an intermediate stage in resynthesis, while Cramer and Ludford (1925) show that the golgi apparatus may be the cell structure mainly concerned, and that mitochondria do not appear to take an active part in the process of fat absorption. Sinclair (1929), adopting a chemical point of view, finds that during the absorption of fat there is a pronounced change in the composition but no change in the amount of phospholipid fatty-acids of the intestinal mucosa and of the liver. He suggests that absorbed fatty-acids are transformed into phospholipids in the cells of the intestinal mucosa, as an essential step in the resynthesis of fat.

\section{Brief Statement on the Technique of Fat Staining.}

Albrecht applied the term "liposome" to small refractive droplets observed in freshly mounted sections of liver and other tissues. These droplets appear more numerous and more sharply defined if the sections are cleared in potassium hydroxide solution before mounting. But they are not proven to be entirely lipoid in character, and Bell (1910) uses the term in a more restricted sense to denote such of these drops as may also be stained with Herxheimer's Scarlet Red $(2 \cdot 0 \mathrm{gm}$. NaOH added to 100 c.c. of 70 per cent alcohol with subsequent addition of Scarlet Red to saturation). Osmic acid and simple alcoholic solutions of Scarlet Red and Sudan will stain many of the liposomes but do not invariably give positive results. Altmann (1894) demonstrated the reduction of osmic acid by oleic acid and triolein and showed that no reduction takes place with tripalmitin, tristearin or their acids. Starke (1895) and others, maintain that osmic acid will blacken all fat if sections are kept for some time in alcohol after the osmic treatment. He concluded that palmitin and stearin do reduce osmic acid, and Handwerck (1898) agreed with him, but maintained that at least a trace of olein was essential if reduction was to occur. Heidenhain (1907) rejected the osmic-alcohol treatment, which blackens bodies that are not true fat and does not affect others which undoubtedly are fat. Mann showed that osmic acid may be reduced and hydrated by alcohol into $\mathrm{OS}\left(\mathrm{OH}_{4}\right)$ and rejected the osmic-alcohol treatment. Bell (1910) found that " on the whole osmic acid is a useful reagent for the study of liposomes. It often gives a brown colour to droplets not stained at all by the simple alcoholic solutions of Scarlet Red and Sudan." Gatenby (1919) holds that the blackening effect of osmic acid can take place in the presence of a chrome compound, e.g. chromic acid, and that fresh palmitin and stearin are blackened by osmic acid after treatment with formalin. In the Microtomists' Vade-Mecum (1928) 
we are told that " the true fats and the lipoids are all blackened by osmic acid," and that the various groups differ in the readiness with which they are blackened as well as in the depth of blackening produced. True fats blacken most readily and deeply, while substances such as cholesterol are not readily blackened. Treatment with bichromate solutions accentuates these properties and prevents substances showing only weak reducing powers from reducing osmic acid, so that after such treatment only true fats and fatty-acid, cholesterin mixtures are blackened. In order to examine lipoids, Ciaccio fixed tissues in a formalin-bichromate acetic mixture which he believed fixes lecithin so that it is not removed by the ordinary fat solvents. Bell maintained that it is not proven that the droplets so preserved consist of lecithin. Ciaccio (1921) preserved fatty acids of the saturated series by fixing small pieces of tissue in a saturated solution of zinc acetate, staining sections with Sudan or Scarlet Red.

\section{Material and Methods.}

The fish used in the following experiments were trawled in Cawsand Bay or in the nearby vicinity by s.s. Salpa of the Marine Biological Association. As soon as possible after trawling they were placed under circulation and later transferred to fish-boxes in the pond at Pier Cellars, boxes such as are at present being used in connection with work on Growth and Maintenance in the Plaice, and were allowed to become settled. Individuals showing signs of any ill-effect due to trawling were removed at once and the remainder were fed regularly on a diet of Mytilus edulis fragments. All the fish used took food avidly and were apparently perfectly sound, and the physical conditions under which they were kept approximated closely to the natural ones, the fish living in boxes in the sea.

Primarily, a number of fish were fasted for several days, after which they were killed by a blow on the head which pithed the brain and the tissues of various regions of the alimentary tract were appropriately fixed to serve as controls. Other fishes were fasted for two or three days, fed in various ways and killed the requisite number of hours afterwards in order to preserve tissues in various stages of absorption. Several lines of treatment were adopted. In some cases, a single meal of Mytilus or Nereis was supplied, the time at which food was taken being noted. In other cases, a second meal of similar food was given at various times after the first, but usually about twenty-four hours later. Because of the great avidity shown by the fish for food, the stomach was invariably filled during a few minutes following the presentation of food, while the fish were still under observation. Thus the times could be recorded with great accuracy. Several fishes were given olive oil or olive oil emulsion 
meals by injection through the mouth both during the "empty" condition of the gut and also following upon a meal. And, finally, a. number of fishes were fed for several consecutive days upon Mytilus fragments liberally mixed with olive oil. Freshly trawled fish were used in several instances.

Several methods of fixation were employed. Initially frozen sections. were prepared of material fixed in $10 \%$ formalin, which sections were stained with Sudan or osmic acid. But this method was discontinued in favour of more applicable ones. Some material was fixed in equal parts of Müller's fluid and 1\% osmic acid, but only in a few instances could this method be regarded as successful. Comparison was afforded with tissues fixed by Kolatschev's slightly modified Champy fluid, and this latter fixative was largely used subsequently with great success. Tissues. were kept for 24 hours in fluid consisting of 4 parts of $1 \%$ chromic acid, 4 parts of $3 \%$ potassium dichromate, and 2 parts of $2 \%$ osmic acid. They were washed for several hours in running water and treated for 3 days with $1 \%$ osmic acid. Sections were mounted in xylol balsam, Apathy's gum syrup and glycerine, those in balsam lasting well.

Materials corresponding to those fixed in Champy fluid were also fixed by Ciaccio's method (Schmorl, 1925) in a mixture consisting of 80 c.c. of $5 \%$ potassium bichromate, 20 c.c. of formaldehyde, and 5 c.c. of glacial acetic acid. This was followed by treatment for 5-8 days in a $3 \%$ solution of potassium dichromate, after which the tissues were washed for 24 hours in running water and passed through alcohols and xylol to wax in the usual manner. This technique is claimed to preserve lipoids, although true fats are removed in the alcohols and xylol. A potent solution of Sudan was obtained by dissolving the dye in boiling. $85 \%$ alcohol, as Fischer suggested for fats. To 95 c.c. of this solution, 5 c.c. of acetone were added and the stain applied to the sections for an hour or more at a temperature of about $30^{\circ} \mathrm{C}$. The sections were then differentiated and counterstained faintly with iron hæmatoxylin. This technique also gave good results. The mounting medium employed was. Apathy's gum syrup.

\section{Notes on the Morphology and Histology of the Alimentary Tract.}

The alimentary tract of the plaice is differentiated into regions, of which the important ones from the point of view of absorption are stomach, duodenum, intestine and rectum. The stomach comprises about $\frac{1}{6}$ th of the entire length of the tract and is separated from more posterior regions by the pyloric valve. The post-pyloric intestine, which takes up approximately half the whole length of the tract, is for convenience. 
regarded as consisting of two equally long regions, the duodenum and intestine. Four very small pyloric cæca open into the duodenum immediately posterior to the pylorus. The terminal portion of the tract or rectum is separated from the intestine by a second valve, the intestinorectal valve.

Histologically, the tract consists of a serosa, outer longitudinal and inner circular muscle bands, an areolar tissue layer and a mucous membrane. The mucous membrane of the stomach is very thick, being formed into numerous simple, or slightly branched, tubular glands consisting of three types of cell, (1) columnar cells forming a superficial epithelium, which is continued into the crypts marking the openings of the glands, (2) cubical, mucus-producing cells, which form the neck of each gland and (3) granular cells which build up the basal portions of the gland tubules. Processes of the areolar tissue layer pass between adjacent gland tubules. In the duodenum, with its pyloric cæca, intestine and rectum, the mucous membrane consists of a simple epithelium of extremely tall and slender columnar cells interspersed with goblet cells. It is gently corrugated into a large number of folds which simulate, but are not, villi. The areolar tissue layer follows the mucosal folds, passing into the tips of even the most slender of these. The degree of mucosal folding is much greater in the pyloric cæca than in other parts of the post-pyloric intestine.

\section{Protocols.}

(1) Plaice, $20.0 \mathrm{~cm}$. in length, killed 30 hours after taking a single meal of Mytilus fragments. Tissues fixed by modified Champy and Ciaccio methods.

Stomach.-The superficial epithelium shows a moderately heavy loading with fat, in osmicated material, although some folds are relatively fat free. Fat globules are relatively scarce in the cells of the crypts and altogether absent from the mucus-producing cells forming the necks of the glands (Fig. 1). The cells of the basal portions of the gland tubules each contain several fat globules ranging in numbers from one or two to about ten (Fig. 1). The areolar tissue layer is devoid of fat. In the cells of the superficial epithelium the fat globules are distributed on each side of the nucleus, but are larger and more numerous on the outer aspect of it. The outer $\frac{1}{5}$ th part of each cell is devoid of fat (the clear cell margin takes up rather less than half of this). The next deeper ${ }_{5}^{1}$ th part is densely crowded with moderately large globules, below which comes the region of the nucleus, where there are no globules. Smaller globules occur below the nucleus, extending to within $\frac{1}{5}$ th part of the depth of the cell from the base (Fig. 2).

In chromed material, fine, Sudan-stained lipoid granules are distributed 
somewhat similarly to osmicated fat. The outer halves of the cells are crowded but the outer $\frac{1}{5}$ th is clear. In some parts of the epithelium, granules occur in groups below the nucleus, but these are not as common as are the fat globules.

Duodenum.-Fine Sudan-stained lipoid granules are crowded in the

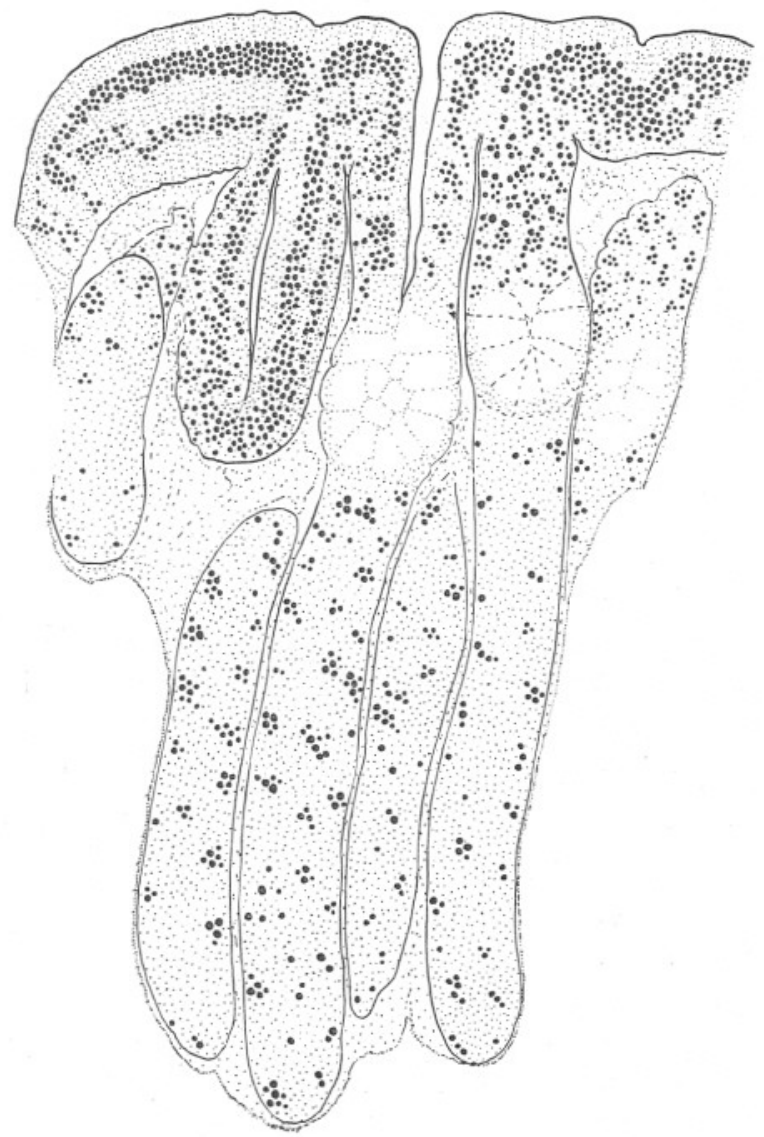

FIg. 1.-Vertical section of the gastric epithelium of the plaice referred to in Protocol (1). Unstained preparation of Nassanow-Champy-Kull material. Showing the loading of the superficial epithelium and the basal cells of the gland tubules with fat, and also the absence of fat from the mucus. producing cells forming the necks of the gland tubules. $\times 460$.

outer halves of the cells at the tips of the mucosal folds. In osmicated material, corresponding cells show crowds of minute, brown-stained, and in some cases blackened, particles. The cells of the mucosal troughs are blank.

In all other regions of the alimentary tract fat globules are absent. NEW SERIES.-VOL. XVII. NO. 1. SEPTEMBER, 1930. 
(2) Plaice, $17.8 \mathrm{~cm}$. in length, killed 50 hours after taking a single meal of Mytilus fragments. Fixation as before.

Stomach.-The loading of the superficial epithelium with osmicable fat globules is greater than that after 30 hours' digestion (Protocol 1).

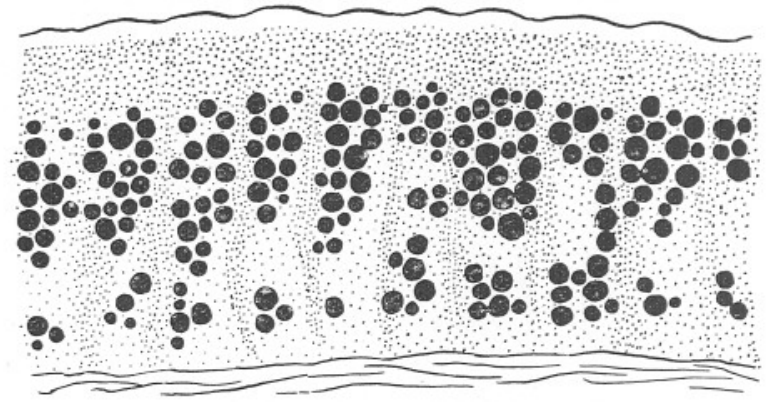

FIG. 2.-Vertical section of the superficial epithelium of the stomach of the fish referred to in Protocol (1). Unstained preparation. Tissue fixed by modified Champy-Kull. The sizes and distribution of the fat globules have been rendered as accurately as possible. $\times 1300$.

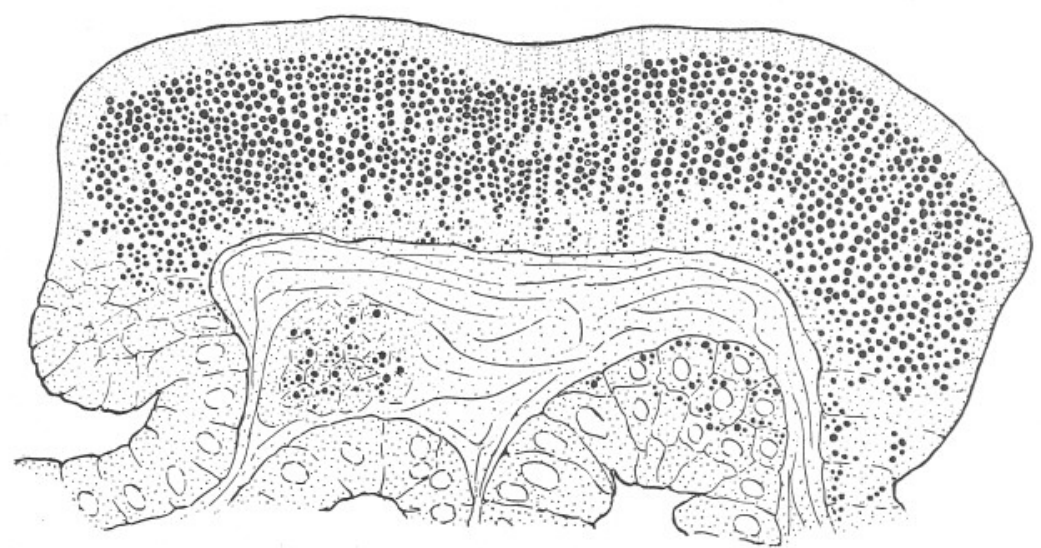

FIg. 3.-Vertical section of the gastric mucosa of the plaice referred to in Protocol (2). Unstained preparation. C.-K. fixation. Showing a heavy loading of the superficial epithelium with fat except in the parts lining the crypts, where fat is relatively sparsely distributed. $\times 780$.

The outer $\frac{1}{6}$ th of each cell is clear, while in the body of each cell large droplets are arranged in two or three longitudinal rows lying so close as almost to touch each other (Fig. 3). In some folds, however, there is but little fat, as before. Fat is also relatively scarce in the cells lining the crypts (Fig. 3), whilst in the mucus-producing cells of the neck and the basal cells of the tubules fat is absent. Nor does fat occur in the areolar 
tissue layer. In the gastric epithelium adjacent to the pyloric sphincter, where gastric glands do not occur, there is a considerable loading with fat droplets, which is not as heavy as in the glandular part of the stomach.

In chromed material, minute Sudan-stained lipoid granules are to be found crowded in the cells of the superficial epithelium. They occur in all parts of the cells but appear to be more numerous and more densely aggregated in the basal parts. They are much smaller than the droplets observed in osmicated material. The mucus-producing cells and basal cells of the tubules do not show such granules, although the latter cells

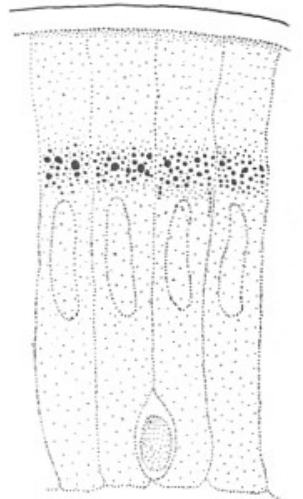

FIG. 4.-Vertical section of the intestinal epithelium of the plaice referred to in Protocol (2). Unstained preparation. C.-K. fixation. Showing the first stage apparent during fat absorption. Small droplets appear about ${ }_{3}^{1} \mathrm{rd}$ of the depth of the epithelium from the outer boundary. $\times 1100$.

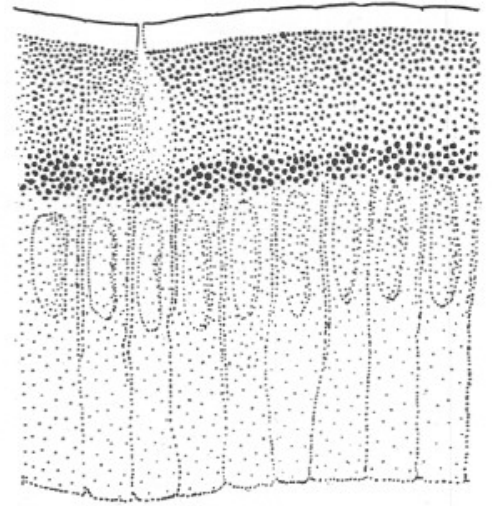

FIG. 5.-Vertical section of the intestinal epithelium of the plaice referred to in Protocol (2). The stage of fat absorption shown is slightly later than that shown in Figure 4. The droplets noted in Figure 4 are here enlarged and brown-stained and smaller droplets occur between these and the clear, cell margin. Unstained preparation. Fixation by C.-K. $\times 1100$.

show dense aggregations of greyish stained granules in the half of the cells bordering the gland duct.

Pyloric caeca and Duodenum.-In osmicated material, cells near the tips of the mucosal folds show moderately dense clusters of extremely minute granules few of which are completely blackened. By far the greater part of the mucosa is devoid of fat, but clusters of cells are found to be partly filled with fairly large globules. These clusters occur in both duodenum and cæca but rarely.

Intestine.-Fat droplets are far more numerous than in the duodenal epithelium. They appear in the tips and limbs of almost every fold. In most folds they occur as extremely minute blackened bodies occupying a fixed position within the cells about $\frac{1}{3}$ rd of the depth of the cells from the 
clear margin (Fig. 4), so that under low powers of the microscope a thin, dark line follows the folds of the epithelium. But in some folds or portions of folds, larger droplets occupy this fixed position, the cytoplasm between these and the clear cell margin being densely crowded with smaller droplets (Fig. 5). In a few cells, small globules have been formed.

Minute, Sudan-stained granules are abundant in Ciaccio fixed material. These completely fill the outer halves of the epithelial cells, extending close up to the clear cell borders (Fig. 6). Undoubtedly, many of these granules appear brownish in colour in Champy fixed material. But there is no size differentiation in any parts of the epithelial folds and the granules are more numerous than the osmicated droplets.

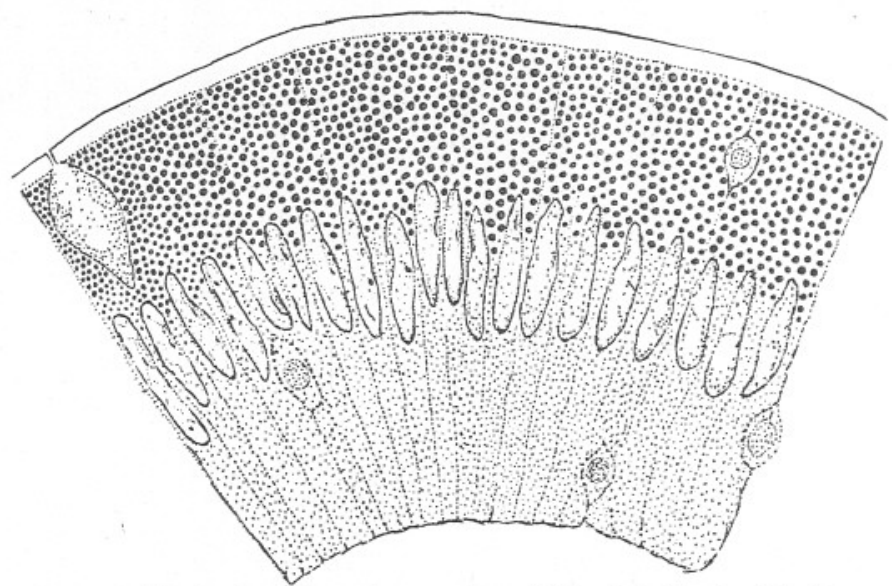

FIG. 6.-Vertical section of a portion of the intestinal epithelium of the plaice referred to in Protocol (2). From the limb of a mucosal fold. Fixation of tissue by modified Ciaccio. Stained with Sudan and iron hæmatoxylin. Showing the outer halves of the cells crowded with lipoid granules. $\times 1100$.

(3) Plaice, $24.4 \mathrm{~cm}$. in length; given a mussel meal, interval of $26 \frac{3}{4}$ hours, given a second mussel meal and killed 19 hours later. Fixation as before.

Stomach.-There is little or no osmicated fat in the superficial epithelium, except in the region of the pyloric sphincter, where the cells contain numerous small globules chiefly occupying a basal position.

In Ciaccio fixed material there are no Sudan-stained lipoid granules.

Duodenum and Pyloric caca.-The epithelial cells are very heavily loaded with osmicated fat, especially in the tips and limbs of the mucosal folds, where the outer halves of the cells are rendered almost opaque with fairly large globules (Fig. 7). The inner halves of the cells contain fewer and smaller globules although much fat is present. In the heavily 
loaded cells only the thin, clear cell margins are without globules. Stretches of epithelium, forming the limbs or troughs of the mucosal folds, do not contain fat, so that a single fold may carry much fat and yet possess cells without it. (Fig. 7 shows how the fat content of adjacent cells varies.) In the areolar tissue layer very small clusters of extremely minute droplets occur here and there, but generally, the layer does not contain osmicated fat.

In Ciaccio fixed material, minute, Sudan-stained lipoid granules occur in all parts of the mucosa, i.e. in the tips, limbs and troughs of the folds. The granules are very numerous, crowding the outer halves of the cells. In some cases the outer $\frac{1}{5}$ th part of the cell is relatively clear of granules,

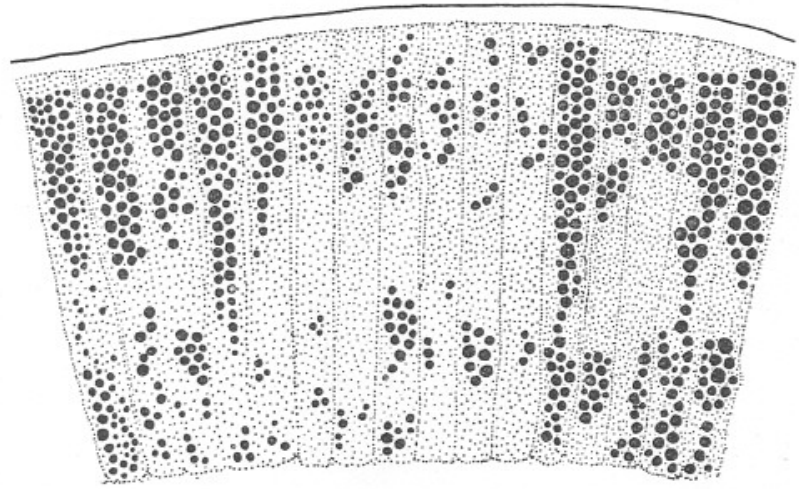

Fig. 7.-Vertical section of a portion of the duodenal epithelium of the plaice to which reference is made in Protocol (3). From the limb of a mucosal fold. Unstained preparation. Fixation by C.-K. Showing how the fat loading varies in different cells lying close together. The maximum load shown here is not the heaviest seen in this epithelium. $\times 1000$.

but generally the granules extend close up to the clear cell border. In the troughs of the mucosal folds granules occur in a basal position within the cells also, where they are slightly larger. Large masses of granules also occur in the areolar tissue layer (c.p. with absence of osmicated fat).

Intestine.-The loading of the epithelium with osmicated fat is similar to but not as heavy as that in the duodenum. Smaller globules occur in the outer halves of the cells while the inner halves are clearer. The areolar tissue layer is devoid of osmicated fat.

Sudan-stained lipoid granules are just as abundant as in the duodenum, especially in the tips of the folds. But few granules occur in the areolar tissue layer.

Rectum.- Small fat droplets and globules occur in osmicated material but rarely. There is little absorption. Similarly in Ciaccio fixed material, 
a few Sudan-stained granules occur in some cells, but the vast majority of cells are devoid of them.

Liver.-Much osmicated fat is present in the liver cells, the globules being of all sizes from very large to minute. But there are no lipoid granules present.

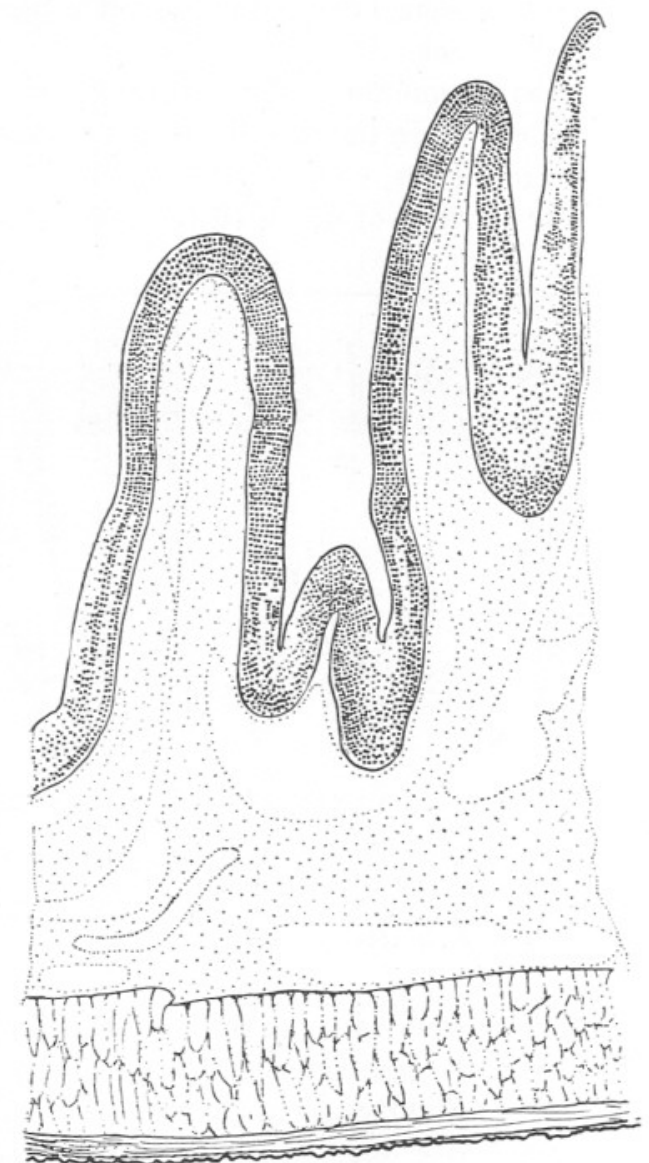

FIG. 8.-Transverse section of the intestine of the plaice referred to in Protocol (4). -Unstained preparation. Fixation by C.-K. Showing the epithelium heavily charged with fat and also the fat-free areolar tissue layer. $\times 90$.

(4) Plaice, $23.3 \mathrm{~cm}$. in length; given a mussel meal, interval of 48 hours, given an injection of olive oil emulsion $(\mathrm{pH}=8 \cdot 3)$ through the mouth and killed $50 \frac{1}{4}$ hours later. Fixation as before.

Stomach.-Practically no absorption of fat or lipoids has taken place. Small osmicated globules and Sudan-stained granules occur but very rarely. 
Duodenum and Pyloric caca.-In osmicated material, the cells of the tips of the mucosal folds show a fairly heavy loading with fat globules. In the cells forming the limbs of the folds fat is not as abundant, the globules being confined chiefly to the central zones of the cells. Some folds are relatively free from fat. Fat is absent from the areolar tissue layer.

In Ciaccio-fixed material, there are no Sudan-stained, lipoid granules. These are absent from the epithelial and areolar tissue layers.

Intestine.-The epithelium is very heavily loaded with osmicated fat in all parts of the mucosa, i.e. in the tips, limbs and troughs of the folds (Fig. 8). The tips of the folds contain most fat, large globules completely

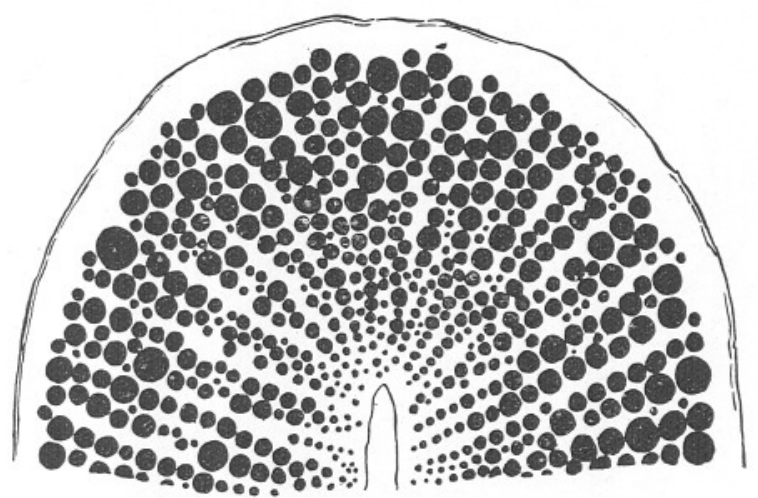

FIG. 9.-Vertical section of the epithelium forming the tip of a mucosal fold from the intestine of the plaice referred to in Protocol (4). Unstained preparation. Fixation by C.-K. Showing the maximal loading of the epithelium with fat. The size and distribution of the globules shown has been carefully treated. $\times 800$.

filling the cells from the clear, outer hems to the basal parts. Near the bases of the cells the globules become smaller (Fig. 9). There is not a trace of osmicated fat in the areolar tissue layer (Fig. 8).

Ciaccio-fixed tissue shows the absence of Sudan-stained lipoid granules from all layers of the tract. In the epithelial cells, the vacuoles left after the removal of true fats by alcohols and xylol following the chroming treatment, are most conspicuous (Fig. 10). There is no trace of granules in the areolar tissue layer.

Rectum.-Neither osmicated fat globules nor Sudan-stained lipoid granules occur in any part of the epithelial or areolar tissue layers.

(5) Plaice, $29.0 \mathrm{~cm}$. in length; killed after fasting for 6 days. Fixation by Kolatschev's modified Champy method.

Stomach.-Osmicated fat globules occur in all parts of the superficial 
epithelium. In the parts lining the crypts of the gastric glands, the globules are few in number and localised in the basal portions of the cells (Fig. 11), while in the parts between adjacent crypts they occur also to some extent in the outer halves of the cells. The globules are generally much smaller than those occurring during fat absorption.

Occasionally a few minute globules occur in the mucus-producing cells forming the necks of the gland. But a small cluster of moderately large globules occurs in the basal cells of each tubule, these presenting a constant feature. The numbers vary, some cells possessing only one or

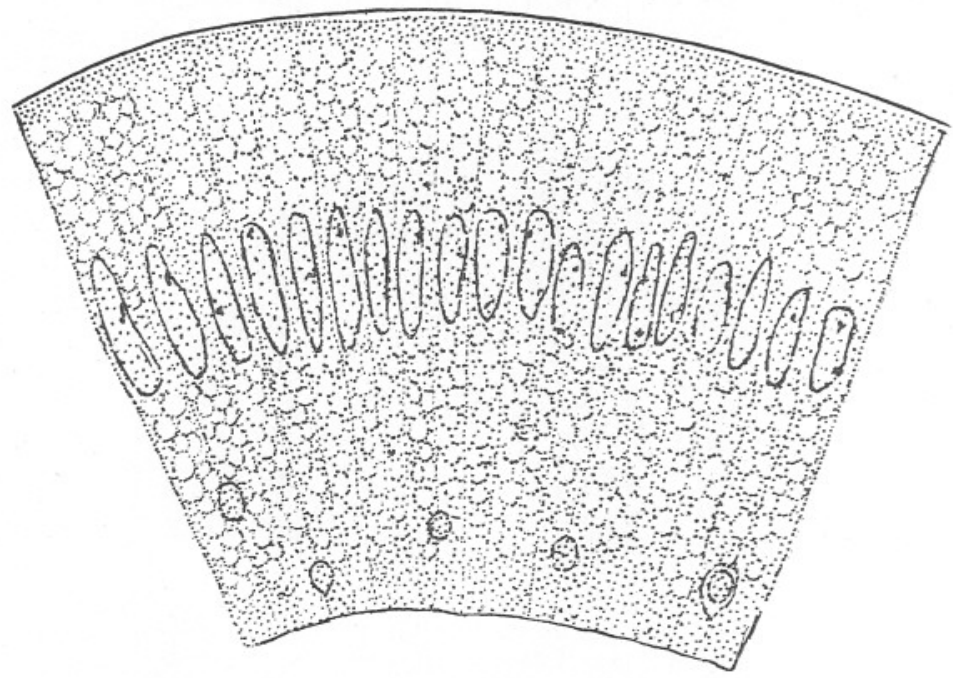

FIG. 10.-Vertical section of the intestinal epithelium of the plaice referred to in Protocol (4). Fixation by modified Ciaccio. Staining with Sudan and iron hæmatoxylin. Showing the absence of lipoid granules and the vacuoles left in the cytoplasm of the cells after removal of fats by the solvents employed in this technique. $\times 1300$.

two, others six or seven, but every cell appears to contain fat (Fig. 11). There is no trace of fat in the areolar tissue layer.

All the fat described above is capable of extraction if sections are left overnight in turpentine.

The epithelial and areolar tissue layers of more posterior parts of the alimentary tract, i.e. of the duodenum and pyloric cæca, intestine and rectum, are free from fat and provide perfect blanks.

(6) Plaice, $28.5 \mathrm{~cm}$. in length; killed after fasting for 6 days. Fixation as before.

Stomach.-Fat is present in the superficial epithelium, its distribution closely following that of the fat observed in the corresponding cells in the 
$29.0 \mathrm{~cm}$. plaice described in Protocol (5). The neck-cells are similarly without fat, which is also absent from most of the deeper glandular cells. There is no fat in the areolar tissue layer.

Perfect blanks are obtained from all post-pyloric regions of the tract in every layer.

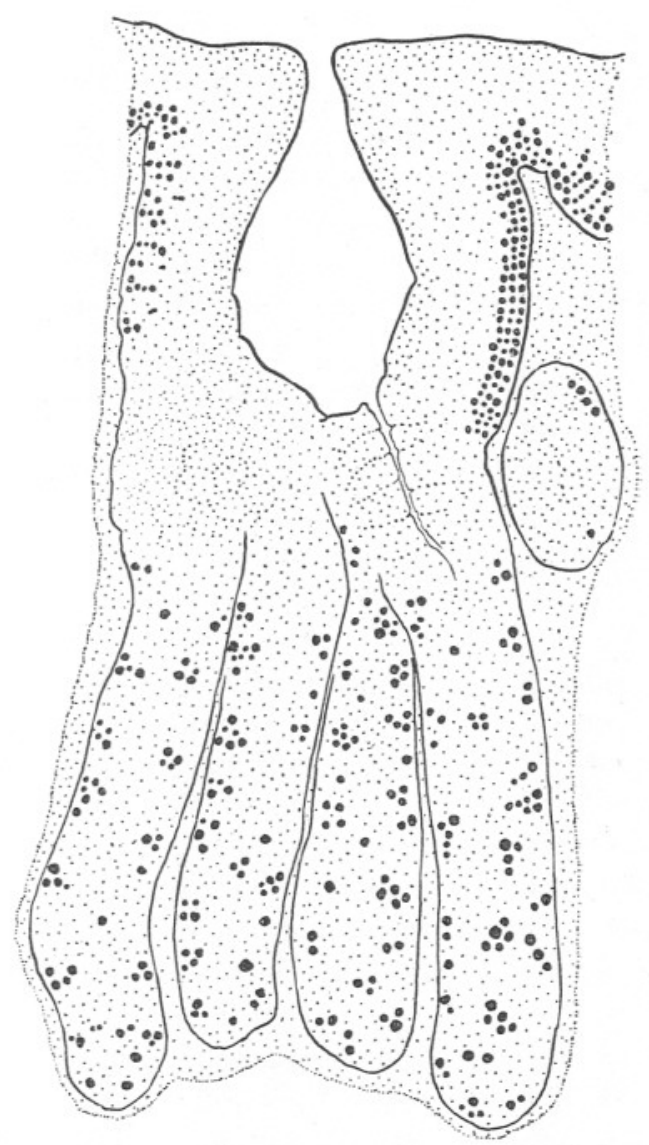

Fig. 11.-Vertical section of the gastric epithelium of the plaice referred to in Protocol (5). Unstained preparation. Fixation by C.-K. Showing the distribution of fat globules in the superficial epithelium, and the basal cells of the gland tubules and the absence of fat from the mucus-producing cells forming the necks of the tubules. $\times 500$.

(7) Plaice, $28.4 \mathrm{~cm}$. in length; killed after fasting for 7 days. Fixation. as before.

Stomach.-There is no osmicated fat in the cells of the superficial epithelium. The mucus-producing cells of the neck of the glands. 
similarly are without fat. But the basal cells of the gland tubules show fat globules as seen in the $28.5 \mathrm{~cm}$. plaice of Protocol (6). The areolar tissue layer is without fat.

Note.-In a fish $(32.5 \mathrm{~cm}$.) killed after fasting for 6 days, Sudanstained lipoid granules were absent from all regions of the alimentary tract.

\section{Absorption of Fats and Lipoids in the Stomach.}

The stomach of a plaice which has been fasted for six or seven days is usually collapsed and contains a small quantity of clear fluid apparently rich in mucin. Fat is to be found in the epithelial layer of all parts of the organ after such a fast. It occurs in the form of small globules localised chiefly in a basal position within the cells (in the epithelium lining the crypts) (Fig. 11), but also in the outer halves of certain cells (in the epithelium between adjacent crypts). The mucus-producing cells may contain each a few minute fat droplets but may be altogether without fat (Fig. 11). The basal cells of the tubules contain fat in variable quantities at the end of such a fasting period. In some cases every cell appears to contain a number of large globules, in others many cells may be without even droplets (Fig. 11). Fat does not occur in the areolar tissue layer.

In fish killed 30 hours after taking a single meal of Mytilus fragments, following on a period of fasting, the superficial epithelium shows an increased loading with fat globules. Only the outer $\frac{1}{5}$ th part of each cell is consistently free from fat (Fig. 1). Below this zone fairly large globules are densely aggregated outside the nuclear zone, and rather smaller globules inside the nuclear zone extend to within $\frac{1}{5}$ th of the depth of the cell from the base. The superficial epithelium lining the crypts of the glands shows a relatively lighter loading with fat, although more is present than after a period of fasting (c.p. Figs. 1 and 11). Fat is completely absent from the mucus-producing cells forming the necks of the tubules (Fig. 1), but globules occur in the basal cells of the tubules. After 50 hours of gastric digestion and absorption of Mytilus fragments, the loading of the superficial epithelium with fat is further increased (c.p. Figs. 3 and 1). The clear, outer zone is narrower and fat globules are so densely crowded into the outer halves of the cells as in many cases to render these parts solidly black in appearance under low powers of the microscope. Two or three longitudinal rows of globules are contained within a single cell, these rows extending closer to the basal margin of the epithelium than hitherto (c.p. Figs. 1 and 3). But there has been no passage of fat into the mucus-producing cells of the glands nor is there any sign of fat in the basal cells of the tubules. It is not possible to trace the fate of the fat observed in these latter cells after 
a fast and during the earlier stages of digestion. It does not reappear while active digestion is taking place, so that it may be a metabolite during the process of digestion. The areolar tissue layer is devoid of fat droplets, so that if fatty elements are passed through this layer into the blood-stream, either there is no resynthesis of the elements or the resynthesised fat globules are so small as to be incapable of resolution under the highest powers of the microscope. After a single mussel meal then, the stomach is capable of fat absorption, the superficial epithelium being the most important element of the mucosa thus concerned.

In both cases of digestion and absorption of Mytilus fragments noted above, lipoid granules show a distribution similar to that of true fat globules. The granules are smaller in size, and although present in larger numbers they do not form the same bulk as the fat globules.

After the digestion of two mussel meals there is hardly a trace of fat in the superficial epithelium of the stomach, although considerable absorption has taken place in post-pyloric regions of the alimentary tract as shown by tissues subjected to precisely the same details of technique. In a fish $18.7 \mathrm{~cm}$. long (not included in the protocols), which was supplied with six consecutive meals of Mytilus fragments liberally mixed with olive oil at 24-hour intervals and was killed 48 hours after the last meal, there was a loading of the superficial epithelium with fat globules yet not as heavy a loading as was obtained in the other fish killed about 50 hours after a single mussel meal. The probable significance of these findings is discussed briefly in the next part of this paper.

\section{Absorption in the Duodenum, Pyloric cæca, Intestine AND Rectum.}

During a period of fasting, various changes occur in the condition of the alimentary tract of the plaice. Usually, as has been mentioned, the stomach is collapsed and empty or almost empty of fluid, but it may be filled to distention with clear fluid. The condition of the post-pyloric part of the alimentary tract also changes during such a period. The duodenum, which is the anterior half of that portion of the tract included between the pyloric and intestino-rectal valves, is usually moderately distended with clear, watery fluid but may be greatly distended or, on the other hand, contracted and empty. This also holds for the intestine and rectum. There appears to be some correlation between the conditions of the tract in the various regions, for when the duodenum is collapsed, the intestine is usually greatly distended, when the intestine is collapsed and empty, the rectum is full to distention. The changes from region to region at different times are similar to those occurring during the active 
digestion of food, the same peristaltic activity of the walls of the tract being in evidence. The rectum assumes insignificant proportions when collapsed, but its walls are capable of greater distention than obtains in any part of the intestine anterior to the rectum. It holds a considerable volume of fluid at certain times, but whether the bulk of this fluid is removed by absorption or by way of the anus has not been determined, although it is shown that the rectal epithelium can absorb fats to some slight extent.

In fish supplied with a single meal following upon a period of fasting, changes similar to those mentioned above are observed. For a number of hours after the meal is taken, the stomach is greatly distended with food, while the more posterior regions are either distended with clear, colourless fluid or are collapsed and almost empty of fluid. In a number of experiments on the rate of digestion, the results of which are as yet unpublished, it was found that, at summer temperatures such as obtained when the observations on fat absorption were made, and when Mytilus edulis is the food supplied, the fluid in the duodenum is clear in fish killed 15 hours $(16.7 \mathrm{~cm}$.$) and 16$ hours $(14.7 \mathrm{~cm}$.) after taking a single meal. But in fish killed $18 \frac{1}{4}$ hours $\left(20 \cdot 1 \mathrm{~cm}\right.$.) and $18 \frac{1}{3}$ hours $(15 \cdot 8 \mathrm{~cm}$.) after taking a single meal, the fluid in this part of the tract is yellowish in colour and contains shreds of finely divided solid food, which are seen to be in the act of passing through the pylorus. Thus the first slight relaxation of the sphincter takes place at from 16 to $18 \frac{1}{4}$ hours after taking a single meal. Such times as have been noted are likely to vary with variations in temperature, but with this we have no concern at present. It is interesting to note, however, that when Nereis is supplied as food but other conditions identical, the times were different. After $22 \frac{1}{2}$ hours $(19 \cdot 0 \mathrm{~cm}$.) the stomach is greatly distended and the duodenal fluid clear, but after 24 hours $(21.5 \mathrm{~cm}$.) the duodenum contains brownish fluid but no solid, the stomach being greatly distended. With Nereid worm as food, therefore, the sphincter is not relaxed until almost 24 hours have elapsed since the taking of food. The results given above are taken from a much larger mass of data.

Then it was found that the stomach of the plaice retains food for a period of from 40 to 48 hours after the time of taking food. At the first relaxation of the sphincter and for a number of hours afterwards, only fluid and finely-divided solid particles, forming some at least of the products of the gastric digestion of Mytilus or Nereis fragments, are allowed to pass through into the duodenum, the relaxation being incomplete. Total relaxation of the sphincter occurs at summer temperatures at $40-48$ hours after the taking of food, when large and relatively undigested fragments of food are passed into the duodenum.

The time taken for food to pass along the duodenum into the intestine 
is probably short, but no doubt considerable variations occur; $18 \frac{1}{2}$ hours after taking a mussel meal a plaice shows duodenal contents of a straw colour containing shreds of finely divided solid matter, while clear, colourless fluid fills the intestine $\left(20 \cdot 1 \mathrm{~cm}\right.$.) ; $19 \frac{1}{4}$ hours after a meal is taken, the intestinal contents are coloured like those of the duodenum $\left(19 \cdot 4 \mathrm{~cm}\right.$.). In fishes killed $21,21 \frac{1}{2}$, and 27 hours after taking a mussel meal, the intestine was full of brown fluid containing shreds of solid, while in fishes killed $27 \frac{3}{4}$ and 30 hours respectively after taking food, the anterior part of the intestine was considerably distended with brown fluid, the posterior part being contracted and empty. Only fish originally filling the stomach with food were considered in any of the cases mentioned above. In view of these results, it appears that absorption in the intestine commences within an hour or two, or at most a few hours, of duodenal absorption, and long before the stomach is completely emptied of the solid food remaining from the single meal.

Food appears to stay in the duodenum and intestine for a variable period. In all fish killed 30 or fewer hours after taking a meal only clear fluid was contained in the rectum. In a fish $\left(14.4 \mathrm{~cm}\right.$.) killed $38 \frac{1}{2}$ hours after taking a meal intestine and rectum alike contained brown fluid and finely divided solid. In almost every fish killed after a longer period of digestion the rectum contained fluid coloured with mussel food. In a $16.9 \mathrm{~cm}$. fish killed $39 \frac{3}{4}$ hours after taking a meal, the intestine was contracted and empty, its walls appearing yellow and opaque, while the rectum was distended with brown fluid and finely divided solid. It is seen then that partly digested food remains in the duodenum and intestine for more than 20 hours and that a part of the food of the single meal is passed into the rectum as fluid or finely divided solid before complete relaxation of the pyloric sphincter occurs, i.e. whilst solid food remains in the stomach. The time taken for complete removal of a single meal is not easy to determine. Only finely divided mussel fragments were observed in the posterior part of the tract towards the end of the meal. After 54 hours food particles and brown fluid still remain, but after 60 hours only clear fluid remains in every part of the tract.

Summarising these results for a single mussel meal and taking times from the moment the stomach is filled with food, the following approximations are obtained :-

1. Partial relaxation of pyloric sphincter after from 16-18 hours.

2. Finely divided solid and fluid food reaches intestine after 19 hours.

3. Food particles first reach rectum after 38 hours.

4. Complete relaxation of pyloric sphincter after from 40-48 hours.

5. Alimentary tract finally cleared of food after from 54-60 hours. 


\section{TABLE I.}

Passage of Food through Alimentary Tract of Platce: 2 Meals of Mytilus Fragments.

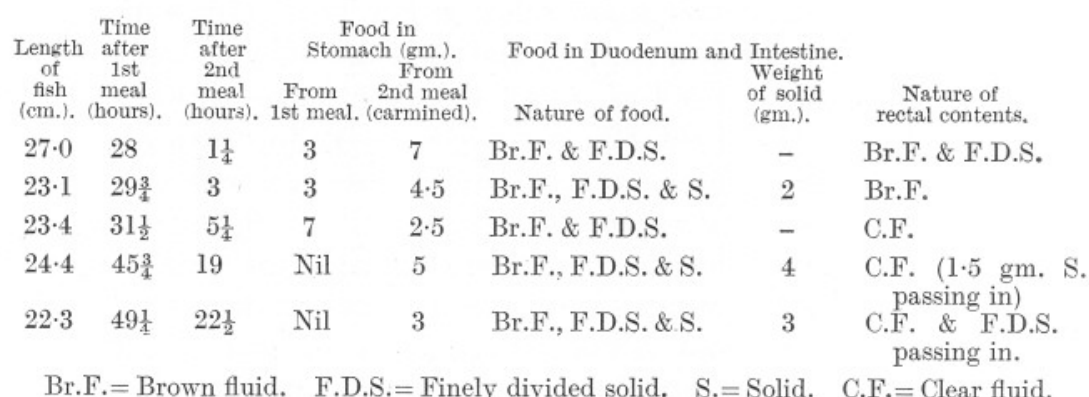

A few experiments were carried out to show what changes, if any, occur in the rate of passage of food through the alimentary tract when 2 meals are supplied on consecutive days, following a period of fasting. The series is incomplete, but the results are sufficiently conclusive to merit their being presented in the accompanying table. The food was supplied in the form of pieces of mussel weighing about $0.2 \mathrm{gm}$., the pieces forming the second meal being covered with carmine particles. Although a cloud of carmine particles pass out through the gills when the fish swallows the food, yet in every case it was possible to distinguish the second meal from the first in the gastric contents. In all these instances presented, the pylorus had been partially relaxed presumably before the second meal was presented, so that the finely divided solid and brown fluid found in the duodenum and intestine in each case is to be expected. Also, since with a single meal the pyloric sphincter is completely relaxed after $40-48$ hours, it is partly anticipated that none of the particles forming the first meal in the last two instances will remain in the stomach. But differences are seen in the rate of progress of the first meal along the tract. It is seen that after 293 hours much of the first meal has passed into the duodenum as large particles of solid. And in two instances food has passed into the rectum after 28 hours, while in another, solid food is passing into the rectum after $45_{4}^{3}$ hours. These results although incomplete suggest that food from a meal passes along the tract more rapidly if a second meal is taken. If completely established the point would be of great significance, since it would be implied that the more frequently the fish takes food, the less efficient it becomes, or more precisely, a fish feeding once per day is less efficient than one taking food on alternate days or less frequently, assuming that digestion of large food particles is also a measure of absorption. 
It is evident from the above results that if a fish is killed 30 hours after taking a meal of Mytilus fragments, following upon a period of fasting, partly digested food materials have been present in the duodenum, in fluid and finely divided solid condition, for approximately 12 hours, and in the intestine for an hour or two, or at most several hours less than 12 . These conditions hold then for the fish to which reference is made in Protocol (1). In this fish it was seen that only the epithelial cells forming the tips of the mucosal folds have undertaken the absorption of fats and lipoids. These cells show lipoid granules and minute brown-stained osmicated particles crowded into their outer halves. There are no granules or fat particles in the cells of the limbs and troughs of the mucosal folds, so that absorption apparently commences in the parts of the mucosa which are likely to project furthest into the lumen of the distended gut.

In a fish killed 50 hours after taking a mussel meal, the duodenum and intestine must have contained food materials, which may or may not have been partly digested in the stomach, in the form of fluid and finely divided solid particles for about 30 hours. In addition, food remaining in bulk after complete gastric digestion has taken place was passed into the duodenum a number of hours (less than 10) previously. These conditions hold then for the fish to which reference is made in Protocol (2). In the duodenum of this fish, fairly dense aggregations of minute fat droplets occur in the cells of the tips of the mucosal folds and groups of cells contain clusters of fairly large globules. In the intestine, what is probably the earliest histologically demonstrable stage in true fat absorption is seen. Extremely minute osmicated droplets occur in a constant position within the cells at about $\frac{1}{3}$ rd of the depth from the clear, outer boundary (Fig. 4). But in corresponding material the whole of the outer halves of the cells from the clear margin to the nuclear zone is crowded with minute lipoid granules (Fig. 6), which are thus more numerous than true fat droplets and also have a wider distribution.

In the case of the fish referred to in Protocol (3), the stomach was distended with carmined Mytilus fragments of the second meal (about $5 \mathrm{gm}$.). The duodenum was distended with brown fluid and fine solid, but also contained about $4 \mathrm{gm}$. of coarser solid. The posterior part was contracted but the intestine was distended, as if food was in the act of passing backwards, which view was supported by the fact that solid particles were passing through the intestino-rectal valve into the clear rectal fluid. The walls of the anterior half of the intestine and the whole duodenum appeared yellow and opaque. Food could not have been in contact with the epithelium of the duodenum and intestine for as long a period as with that of corresponding regions of the fish referred to in Protocol (2), since the times from the taking of the initial meal were 
$45_{4}^{3}$ hours and 50 hours respectively. But more material had been available for duodenal and intestinal absorption, since a portion of the second meal had been passed over. Accordingly an increased degree of absorption might reasonably be anticipated, but not more than twice the amount seen after a single meal. It is to be noted that the mussel samples used in these meals were kept as constant as possible, and that several pieces of tissue from different parts of the same organ were fixed at one and the same time. Comparisons of the data presented briefly in Protocols (2) and (3) show conclusively that the increase in absorption in the post-pyloric part of the tract is very great when two meals are supplied, much more than twice as great.

After two meals, the cells of the tips and limbs of the mucosal folds of the duodenum and intestine, and especially the former, are very heavily loaded with fat globules, so that the outer halves of the cells forming these parts of the folds are rendered solidly black. Only the clear cell margins are devoid of globules. So heavy is the loading that it is not possible to show the detail in a text-figure. The tissue shown in Figure 7 was from a part of the epithelium showing relatively little fat, and was selected to show how cells vary in their fat content. In the case of lipoid granules, there is no considerable increase in numbers within the epithelial layer, but masses of granules occur in the areolar tissue layer, showing that increased absorption of lipoids has ensued.

When it is remembered that after two mussel meals there was little fat and lipoid material in the gastric epithelium, an explanation is afforded for the increased absorption of these materials in the duodenum and intestine. The marked decrease in gastric absorption and equally wellmarked increase in intestinal absorption strongly suggest that the absorptive function is largely transferred from the stomach to the duodenum and intestine when two meals are taken in quick succession, and that the stomach plays a greater part as an organ of absorption when rations are restricted, the post-pyloric intestine assuming the rôle of principal agent of absorption when food is abundant.

The quantity of fat in Mytilus flesh is not very great. According to the most recent analyses (Daniel and Doran (1926)), the fat in the wet flesh of Mytilus edulis ranges from 2.0 per cent before spawning to 0.5 per cent immediately after spawning. The wet flesh also contains cholesterol and probably highly unsaturated fatty acids.

According to Bolles-Lee, not only fats but also cholesterin-fatty acid mixtures are affected by osmic acid following upon treatment with bichromate. Cholesterin alone is unaffected. It appears, therefore, that the droplets browned and blackened by osmic acid during Champy fixation of tissues taken from fish which have digested mussel fragments, are either true fat or cholesterin-fatty acid mixtures. In materials fixed 
by the Ciaccio method used, some of the Sudan-stained granules are undoubtedly those affecting osmic acid also. It may be that these common elements are cholesterin-fatty acid mixtures. It is assumed, out of a consideration of the chemical composition of the food, that Sudan-stained granules not evident in osmicated preparations are granules of cholesterol.

As has already been mentioned, various true fat meals were supplied to certain fish. The fish to which reference is made in Protocol (4) was given an injection of olive oil emulsion prepared by adding phenol phthalein to olive oil and titrating with standard soda to a faint pink $(\mathrm{pH}=8 \cdot 3)$. The alimentary tract had not contained food for two days previously and two days elapsed further before the fish was killed. Thus the absorption of pure oleic fat is being considered. The intestinal epithelium is very heavily loaded with fat in all parts, i.e. in the tips, limbs and troughs of the mucosal folds (Fig. 8). The loading is more consistently heavy than is that in any part of the post-pyloric intestine after two mussel meals. The cells are crowded with osmicated globules of all sizes, those of the mucosal tips being especially densely crowded (Fig. 9). It appears from the evidences afforded, that although there is no histological differentiation in any parts of the post-pyloric epithelia, yet the tips of the mucosal folds play a greater part in fat absorption than do other parts, since absorption commences here and is also more intense.

Lipoid granules are completely absent from all parts of the tract in any region (Fig. 10). It was inferred above that the technique employed favours cholesterin and cholesterin-fatty acid mixtures in Mytilus-fed fish. But it probably affects other lipoids also. The absence of lipoid granules has a special significance. Recently (1929), Sinclair investigated the rôle of phospholipids in fat absorption in mammals, from the chemical point of view. Upon evidence he collected he put forward the hypothesis that, "within the epithelial cells of the intestinal mucosa there is a 'specific' phospholipid which occupies an intermediary position between fatty acids and neutral fat, as represented by the equation :

Fatty acids $\underset{\leftarrow--}{\longrightarrow}$ Phospholipid $\underset{\leftarrow--}{\longrightarrow}$ Neutral fat.

It is an invariable characteristic of this process that the amount of phospholipid remains constant. As soon as fatty acids are absorbed into the epithelial cells molecules of the 'specific' phospholipid react with the free fatty acids (or soaps) to form neutral fat; immediately, however, the phosphoric acid-base complex unites with absorbed fatty acids and glycerol to form phospholipid, thereby maintaining the amount constant." The synthesised molecules of neutral fat coalesce to form droplets.

NEW SERIES.-VOL. XVII. NO. 1. SEPTEMBER, 1930. 
It follows from the above that phospholipid material should be present in cells fixed during active absorption of fats at any time, if only in a form not capable of resolution under the microscope, and especially in cells which have not taken up and resynthesised the cleavage products of fats. In the latter cells it is not unreasonable to anticipate the presence of phospholipid bodies of resolvable size. But in the cells of the intestinal and duodenal epithelium (and also the gastric epithelium) granules such as are preserved with the lipoid technique used are completely absent. It may be that the technique does not favour the "specific" phospholipid, or that the groups of molecules are too small to be visible under the highest powers of the microscope; but in any case, it is not possible to present evidence which supports this hypothesis.

In the duodenum of the emulsion-fed fish, the epithelial cells show relatively less fat than those of the intestine. Fat droplets and globules present in the tips and limbs of the folds are localised in the nuclear zone of the cells, the outer and basal halves of the cells being clear. This is taken as indicating the final stage in fat absorption, when the cells are becoming relieved of the fat they have taken up and when the cleavage products of fats are no longer being presented to the cells from the materials remaining in the lumen of the alimentary tract. Briefly recapitulating the stages observed in fat absorption in the post-pyloric part of the alimentary tract, we have :-

1. The formation of minute fat droplets in a constant cytoplasmic zone about $\frac{1}{3}$ rd of the depth of the cell from the clear cell border (Fig. 4).

2. The formation of minute droplets between the above-mentioned zone and the clear cell border, with contemporary enlargement of the droplets noted in (1) (Fig. 5).

3. The coalescence of minute droplets into globules with which the cells become crowded in all parts, larger globules occurring in the outer halves of the cells (Figs. 7" and 9).

4. The removal of fat in all parts of the cells except the region of the nucleus and the final clearing of the cells.

Only in one or two instances was fat noted in the areolar tissue layer and in these only very few small clusters of extremely minute droplets. From the results thus obtained it is concluded that the cleavage products which pass out of the epithelial layer into the areolar tissue layer are not resynthesised into fats in this layer, unless the process of resynthesis ends with the production of fat droplets so small as to be incapab'e of resolution under the highest powers of the microscope. Even most minute 
droplets appear to be absent. It is beyond the scope of this work to suggest that the cleavage products are passed on to the liver as such, but this appears possible. Lipoid granules are commonly seen in the areolar tissue layer after a mussel meal or meals. And in several fishes not mentioned in the Protocols of this paper the liver contains much fat after a meal, but lipoid granules are completely absent. The blood from the digestive organs is conveyed to the liver by the hepatic portal veins directly, so that either there is no storage of these lipoids in the liver or some chemical transformation takes place in this organ.

The rectum is capable of some slight degree of fat and lipoid absorption, but is not a typical organ of absorption. Small clusters of fat globules and lipoid granules are to be found in some of the rectal epithelial cells during digestion and absorption of a meal. But the quantity of these substances present is negligible from the point of view of practical ends attained.

There is no storage of fat in any part of the post-pyloric division of the alimentary tract.

\section{SUMMARY AND CONCLUSIONS.}

1. Fat occurs in all three types of cell composing the gastric epithelium at the end of a period of fasting extending over 6 or 7 days, but is completely absent from the mucosa of all post-pyloric regions of the alimentary tract at such a time.

2. There is a marked increase in the fat content of the superficial epithelium of the stomach after 30 hours and 50 hours of gastric digestion, the stomach being thus shown to be an effective organ of fat absorption.

3. Considerable quantities of fat are present in the duodenal and intestinal epithelia after fat-containing meals have been digested. The rectum is capable of some slight absorption, although its capacity in this respect is very much smaller than that of the duodenum or intestine.

4. It is suggested that there is a transference of the function of fat absorption from the stomach to the post-pyloric intestine when the frequency with which meals are taken is increased.

5. Globules of true fat are not typically observed in the areolar tissue layer of the alimentary tract, although lipoid granules may occur in abundance. It is suggested that resynthesis of the cleavage products of fats does not occur in this layer.

6. Data are presented bearing upon the rate of digestion of Mytilus edulis and Nereid worm. 


\section{LITERATURE.}

Albrecht, E. 1903. Ueber die Bedeutung myelinogener Substanzen im Zellleben. Deutsche path. Gesellsch., 6.

Aschoff, L. 1909. Zur Morphologie der lipoiden Substanzen. Ziegler's Beiträge, Bd. 47, Hft. 1.

BeLL, E. T. 1909. On the occurrence of fat in the epithelium, cartilage and muscle fibres of the ox. Amer. Journ. Anat., Philadelphia, Vol. 9.

BELL, E. T. 1910. The staining of fats in epithelium and muscle fibres. Anat. Rec., Vol 4.

Bradley, H. C. 1913. The Problem of Enzyme Synthesis. I. Lipase and Fat in Animal Tissues. J. Biol. Chem., 13. II. Diastase and Glycogen of Animal Tissues. Ibid., 13.

CaSH, T. 1880. Ueber den Antheil des Magens und Pankreas an der Verdauung des Fettes. Archiv. für Anat. u. Physiol. Phys. Abt.

Ciaccio, C. 1909. Beitrage zum Studium der Zelllipoide in normalen und pathologischen Verhaltnissen und einer besonderer Entartung von lipoidens Typus (lecithinische Entartung). Centralbl. f. allg. Path. u. path. Anat., Bd. 20, 17.

Ciaccio, C. 1909. Ueber das Vorkommen von Lecithin in den zellularen Entzündungsprodukten und über besondere lipoidbildende Zellen (Lecithinzellen). Ibid., Bd. 20, No. 9.

Ciaccio, C. 1921. Contributo all' istochimica delle sostanze grasse. Sopra un processo per mettere in evidenza gli acidi grassi superior della serie satura. Pathologica, 13.

Daniel, R. J. 1921. Seasonal Changes in the Chemical Composition of the Mussel (Mytilus edulis). Report Lancashire Sea Fisheries Laboratory, No. 30.

Daniel, R. J., and Doran, W. 1926. Some Chemical Constituents of the Mussel. Biochem. Journ., Vol. 20, No. 4.

Dawes, Ben. 1929. The Histology of the Alimentary Tract of the Plaice (Pleuronectes platessa). Quart. Journ. Micr. Sci., Vol. 73, Part II, Oct.

Dolfint, G. 1929. Su un nuovo metoda di colorazione dei grassi. Bull. hist. appl. à la physiol. et à la path., Vol. 6 .

Fischer, B. 1902. Ueber die Fettfarbung mit Sudan III und Scharlach R. Centralbl. f. Allg. Path. u, path. Anat., Bd. 13. 
GAGE, S. H., AND Fish, P. A. 1924. Digestion and Absorption of Fats. Amer. J. Anat., 34.

Gatenby, J. B. 1919. The Identification of Intracellular Structures. Journ. Roy. Micros. Soc. June.

Green, C. W. 1912. Absorption of Fat by the Salmon Stomach. Amer. J. Physiol., Vol. 30.

Green, C. W. 1913. The Fat-Absorbing Function of the Alimentary Tract of the King-Salmon. Bull. U.S. Bur. Fish., Vol. 33.

Hadjiloff, A. 1929. Emploi de solution savonneuse de Soudan pour la coloration du tissu adipeux. Bull. hist. appl. à la physiol. et de la path., 6 .

Handwerck, C. 1898. Beiträge zur Kenntnis vom Verhalten der Fettkörper zu Osmiumsäure und zu Sudan. Zeitschr. f. Wissensch. Mikros. Bd. 15 .

van Herwerden, Mi. 1908. Zur Miagenverdaung der Fishe. Zeitschr. f. Physiol. Chem., Bd. 56.

Herxhermer, G. 1901. Ueber Fettfarbstoffe. Deutsche. Mied. Wochenscrift.

Kastle and Loevenhart. 1900. Concerning lipase, the fat-splitting enzyme, and the reversibility of its action. Amer. Chem. Journ., Vol. 24.

Knolt, A. 1910. Chemische und mikroscopische Untersuchungen den Fetttransport durch die Darmwand bei der Resorption. Pflüger's Archiv., Bd. 136.

Kölliker, A. 1857. Einige Bemerkungen ueber die Resorption des Fettes im Darme, ueber das Vorkommen einer physiologischen Fettleber bei jungen Säug€thieren und ueber die Function der Milz. Verhandl. der Fhys. Med. Ges., Bd. 7.

Krehl, L. 1890. Ein Beitrage zur Fettresorption. Archiv. für Anat. u. Physiol. (Anat. Abt.).

Proescher, F. 1927. Oil Red O Pyridin, a Rapid Fat Stain. Stain Tech., 2.

Schilling, F. 1901. Die Fettresorption im Miagen. Fortschritte der Medicin, Bd. 19.

Sinclatr, R. G. 1929. The Rôle of Phospholipids of the Intestinal Mucosa in Fat Absorption, with Additional Data on the Phospholipids of the Liver and Smooth and Skeletal Muscles. J. Biol. Chem., 82. 
Sмmth, J. L., And Retrie, T. 1924. An Aldehyde Mordant for Fats and Lipoids. J. Path. and Bacteriol., 27.

Smith, J. L., AND Rettie, T. 1928. The Absorption, Deposition and Transport of Fat in the Guinea-pig. Q. J. Exp. Physiol., 19.

Starke, J. 1895. Fettgranula und ein besondere Eigenschaft des Osmium tetraoxydes. Archiv. f. Physiol.

Tranna, R. 1904. Ueber das Verhalten des Fettes und der Zellgranula bei chronischen Marasmus und Hungerzuständen. Ziegler's Beiträge, Bd. 35.

Weiss, O. 1912. Die Resorption des Fettes im Magen. Pflüger's Archiv. für die gesamte Physiol., Bd. 144.

Wells, H. G. 1907. Chemical Pathology. Philadelphia.

The Microtomists' "Vade Mecum," 9th edition, 1928, edited by J. B. Gatenby and E. V. Cowdry. 